\title{
FIRST INTERNATIONAL CONGRESS OF BIORHEOLOGY PREMIER CONGRES INTERNATIONAL DE BIORHEOLOGY
}

\section{4-8. IX. 1972 LYON, FRANCE}

Held in association with

The Sixth International Congress on Rheology

\author{
Under the auspices of The International Committee on Rheology at the \\ University Claude Bernard and the National Institute of Applied Science \\ Organisé conjointement avec \\ Le Sixieme Congrès International de Rhéologie \\ Le Congrès aura lieu à l'Université Claude-Bernard et à \\ l'Institut national des Sciences Appliquées
}

\section{THE INTERNATIONAL SOCIETY OF BIORHEOLOGY}

\section{Officers of the Society}

President: A. L. Copley (U.S.A.), 50 Central Park West, New York, N.Y. 10023.

Vice Presidents: H. HARTERT (Germany), Medizinische Klinik, Städtisches Krankenhaus, 6750 Kaiserslautern, Friedrich-Engels-Straße 25.

S. G. MASON (Canada), Department of Chemistry, McGill University, Montreal.

S. OKa (Japan), Institute of Physics, Keio University, Hiyoshi, Kohoku-ku, Yokohama.

V. I. VoRob'eY (U.S.S.R.), Institute of Cytology, Academy of Sciences of U.S.S.R., 23 Avenue Maklina Leningrad F121.

Secretary General: G. V. F. SEAman (U.S.A.), Division of Neurology, University of Oregon Medical School, Portland, Oregon 97201.

Treasurer: S. WITTE (Germany), Diakonissenkrankenhaus, 75 Karlsruhe 51, Diakonissenstraß 28.

Chairman, Committee on Nomenclature: G. W. Scott Blatr (England), Grist Cottage, Iffley, Oxford, OX4 4EJ.

Liaison Representative to IUPAB: A. SILBERBERG (Israel), Polymer Department, The Wiezmann Institute of Science, Rehovot.

The above nine officers comprize the Executive Council of the Society.

Vice Presidential Secretaries: Secretary to H. Hartert: H. SCHMID-SchönbeIn, Physiologisches Institut Universität, München, 8 München 15, Pettenkoferstraße 12, Germany.

Secretary to S. G. MASON: H. L. Goldsmith, University Medical Clinic, Montreal General Hospital, 1650 Cedar Avenue, Montreal 109, Canada.

Secretaries to S. Oka: E. Fukada, Rikagaku Kenkyusho, The Institute of Physical and Chemical Research, Wako-Shi Saitama, 351, Japan.

L. Dintenfass, Department of Medicine, University of Sydney, Sydney, N.S.W. 2006, Australia.

Secretary to V. I. VOROB'EV: S. J. FrenKEL, Institute of High Molecular Compounds, Leningrad, U.S.S.R.

Assistant Secretary General: Eugene H. Smithberg, Dean of the Graduate School, Newark College of Engineering, Newark, New Jersey 07102, U.S.A. 


\section{FIRST INTERNATIONAL CONGRESS OF BIORHEOLOGY}

Honorary President: J. F. CIER, Honorary Dean, Claude Bernard University, Lyon, France.

M. Bessis, Director, Institut de Pathologie Cellulaire, Hôpital Bicêtre, 94e Kremlin-Bicêtre, France. President: A. L. CoPLEY, New York, U.S.A.

Vice President: A. LARCAN, Nancy, France.

Scientific Organizing Committee:

Chairman: A. L. COPLEY (U.S.A.)

Secretary: A. LARCAN (France)

Members: S. CHIEN (U.S.A.)

M. Joly (France)

N. KAMIYA (Japan)

G. V. F. SeAman (U.S.A.)

A. Silberberg (Israel)

J. F. Stoltz (France)

S. WitTE (West Germany)

\section{PREMIER CONGRES INTERNATIONAL DE BIORHEOLOGY}

Président honoraire: J. F. CreR, Doyen Honoraire, Université Claude-Bernard, Lyon, France.

M. Bessis, Directeur, Institut de Pathologie Cellulaire, Hôpital Bicêtre, 94e Kremlin-Bicêtre, France. Président: A. L. Copley, New York, U.S.A.

Vice-Président: A. LARCAN, Nancy, France.

Comité Scientifique d'Organization:

Président: A. L. COPLEY (U.S.A.)

Secrétaire: A. LARCAN (France)

Membres: S. CHIEN (U.S.A.)

M. Joly (France)

N. KAMIYA (Japan)

G. V. F. SEAMAN (U.S.A.)

A. Silberberg (Israël)

J. F. Stoltz (France)

S. WiTte (Allemagne-Ouest)

\section{ADMINISTRATIVE ORGANIZATION}

The First International Congress of Biorheology is administered by the Organizing Committee of the Sixth International Congress on Rheology. The President of our Society, A. L. Coplex, has appointed A. LARCAN of Nancy, France as liaison officer to represent our Society in the administrative matters.

Le Premier Congrès International de Biorhéologie est administré par le Comité d'Organisation du Sixième Congrès International de Rhéologie. Le Président de notre Société, A. L. Copley, a désigné A. LARCAN, de Nancy, France, comme agent de liaison pour représenter notre Société pour les questions administratives.

\section{SIXTH INTERNATIONAL CONGRESS ON RHEOLOGY}

Honorary President: M. HoRIo, Kyoto, Japan.

President: G. VALLET, Lyon, France.

Vice Presidents: M. JoLY, Paris, France.

Organizing Committee:

$$
\text { B. Persoz, Paris, France. }
$$
VALLET (France)
Vice Chairman: M. JoLY (France)
Secretary: $\quad$ B. PERSOZ (France)
Members: P. BERTICAT (France)
P. COMTE (France)
A. LARCAN (France)
J. R. MAY (France)

Acknowledgements - The International Society of Biorheology and the Scientific Organizing Committee gratefully acknowledge the financial aid received from several sources, including:

Office of Naval Research, United States Department of the Navy, Washington D.C., U.S.A. 
Pergamon Press, Oxford, England and Elmsford, N.Y., U.S.A.

Brookfield Engineering Laboratories, Inc., Stoughton, Mass., U.S.A.

Pioneer Filters Inc., Hillsborough, Oregon, U.S.A.

Schering Corporation, Bloomfield, New Jersey, U.S.A.

The Society also expresses its appreciation of the help rendered by Pergamon Press who printed both the first announcement for the Congress and also the book of abstracts.

The complete list of sponsors will be published in Biorheology. 